IQTISHODUNA

Vol. 16 (2), 2020

P-ISSN: 1829-524X, E-ISSN: 2614-3437

\title{
Online Store Marketing Strategy and Its Implications on Consumptive Behavior in Fashion Products of IAIN Kediri Students: Islamic Marketing and Islamic Consumption Perspective
}

\author{
Naning Fatmawatie \\ IAIN Kediri, Indonesia \\ E-mail: naningfat@gmail.com
}

\begin{abstract}
The online store marketing strategy has made people's lifestyles change to become more modern. This is influenced by culture, mindset, needs and the desire to change. In online store marketing, the distance between sellers and buyers has been very close and transactions can be done easily. This study aims to analyze the implementation of marketing strategies in online stores in Indonesia, analyze the consumptive behavior of IAIN Kediri student fashion products, analyze the practice of marketing strategies to online stores in Indonesia in terms of Islamic marketing and to analyze consumptive behavior in IAIN Kediri student fashion products in terms of consumption of Islam. This research is a descriptive study using a qualitative approach, with a purposive technique as an information determination technique. The result indicates that the online store marketing strategy in Indonesia applies a marketplace, low prices, free shipping and bonus services. The study shows that students of IAIN Kediri spend more through Lazada's online store, on favorite fashion products. The frequency of shopping for fashion products at online stores is at one most once a month and more than one month. The implementation of marketing strategies for online stores must be based on the theistic (rabbaniyyah), ethical (akhlaqiyyah), realistic (al-waqiyyah) and humanistic (insaniyyah) principles.
\end{abstract}

Keywords: strategy marketing, online stores, islamic marketing, islamic consumption.

\begin{abstract}
Abstrak: Strategi pemasaran toko online telah membuat gaya hidup masyarakat berubah menjadi lebih modern. Hal ini dipengaruhi oleh budaya, pola pikir, kebutuhan dan keinginan untuk berubah. Dalam pemasaran toko online, jarak antara penjual dan pembeli sudah sangat dekat dan transaksi dapat dilakukan dengan mudah. Penelitian ini bertujuan untuk menganalisis implementasi strategi pemasaran pada toko online di Indonesia, menganalisis perilaku konsumtif produk fesyen mahasiswa IAIN Kediri, menganalisis praktik strategi pemasaran pada toko online di Indonesia ditinjau dari pemasaran Islami dan menganalisis perilaku konsumtif di IAIN. Produk fashion mahasiswa kediri ditinjau dari konsumsi islam. Penelitian ini merupakan penelitian
\end{abstract}


deskriptif dengan pendekatan kualitatif, dengan teknik purposive sebagai teknik penentuan informasi. Hasil penelitian menunjukkan bahwa strategi pemasaran toko online di Indonesia menggunakan marketplace, harga murah, pengiriman gratis dan layanan bonus. Hasil penelitian menunjukkan bahwa mahasiswa IAIN Kediri menghabiskan lebih banyak uang melalui toko online Lazada, untuk produk fesyen favorit. Frekuensi belanja produk fashion di toko online paling banyak sebulan sekali dan lebih dari satu bulan. Penerapan strategi pemasaran toko online harus didasarkan pada prinsip teistik (rabbaniyyah), etika (akhlaqiyyah), realistik (al-waqiyyah) dan humanistik (insaniyyah).

Kata Kunci: strategi pemasaran, toko online, pemasaran islami, konsumsi islami

| Received March 2020 |Accepted September 2020 | Available online October 2020 | | DOI: http: //dx.doi.org/10.18860/iq.v16i2.8861

\section{How to Cite:}

Fatmawatie. N. (2020). Online Store Marketing Strategy and Its Implications on Consumtive Behavior in Fashion Products of IAIN Kediri Students: Islamic Marketing and Islamic Consumtion Perspective. Iqtishoduna, 16(2), 101-114.

\section{Introduction}

According to Kotler \& Amstrong (2009) that marketing activities are the main goals that play an important role in a company. Marketing is the spearhead in the success of selling products. Communication plays a dominant role in marketing strategies. The development of information and communication technology, among others, the internet is one of the social media that can be used to communicate with each other (Abdel et al., 2010). The benefits of the internet today are not only as a medium of communication, but also used as a means of marketing by business people (Iblasi, 2016; Omar \& Bathgate, 2011). Today, people's lifestyles are beginning to change to become more modern and follow the trends. This is influenced by culture, mindset, needs and also the desire to change. For this reason, many business people take advantage of these trends by using internet to market their products. According to Adelaar (2000); Rahman (2016); Nurdin (2017) that the reason marketers use internet media to market their products, because it is more effective and efficient and easier to

102 | IQTISHODUNA Vol. 16 (2), 2020

http://ejournal.uin-malang.ac.id/index.php/ekonomi 
add networking. The majority of internet users in Indonesia as much as 72.41 percent are still from the urban community. Its utilization has step further, not only to communicate but also to buy goods, order transportation, to do business and work.

According to Pasha dan Reksa (2017) that shopping at online stores is currently a trend and even begins to become a lifestyle in the community. Online product purchases are dominated by teenagers, both men and women. The population of Indonesia currently reaches 262 million people, more than 50 percent or around 143 million people have been connected to the internet throughout 2017 (Buletin APJII, 30 Oktober 2018). Based on its geographical area, the Javanese people mostly use the internet, 57.70 percent. Furthermore, Sumatra 19.09 percent, Kalimantan 7.97 percent, Sulawesi 6.73 percent, Bali-Nusa 5.63 percent, and Maluku-Papua 2.49 percent.

According to Trianingsih (2010) that the increasing number of Indonesians who make purchases online, makes the number of online stores in Indonesia also increasing. In addition, the increase in the population of Indonesia also contributed to the development of the online business. The main reason people prefer shopping through online stores, because: the needs sought are easily obtained, information obtained is easier and does not waste time and energy, information can be sourced from many parties, including personal sources such as: friends, commercial sources such as: advertising, public sources such as: mass media and sources of experience such as: ever using a product. In addition, there are many alternatives such as the number of online stores that become references before buying, so that with ease of information and references, it is easier for prospective buyers to make purchases because there is no need for seduction or persuasion by the seller. And purchases can make purchases for the same item or new goods.

According to Khairunisa (2014) that along with increasing population, the needs, desires and lifestyles of the people also increased. The latest survey of the Snapcart Research Institute in January 2018 revealed that the millennial generation is the most shopper in the field of e-commerce as many as 50 percent (25-34 years). The majority of consumers shopping by gender are women with 65 percent. If combined with generation Z (15-24 years), the number of shopper from the younger generation reaches around 80 percent. This means that young people aged 15-34 years dominate 80 percent of ecommerce users. The development of the amount of online transactions in Indonesia in 2016 reached US \$ 4.89 billion, or around Rp. 68 trillion. 
However, the figure of US \$ 4.89 billion obtained during 2016 was far higher than the nominal value of transactions in 2015 and in 2017 amounting to US \$3.56 billion.

In 2018 IAIN Kediri had 3 faculties, namely Ushuludin, Tarbiyah and Sharia. The total number of IAIN Kediri students in 2018 is 8,232 students. The following is the development of the number of IAIN Kediri students in the last 3 years, namely: in 2016 a total of 3,821 students in which 1,139 students and women 2. 682 students, 2017 a total of 5,439 students where 1,626 men and 3,813 women and 2018 a number 8,232 students in which 2,572 men and 5,660 women.

Based on the description above, researcher is interested in examining the problem of online marketing strategies, with the reasons: the marketing strategy applied by online stores motivates consumers to tend to consumer behavior in online stores; based on the Snapcart Survey, 2018, it can be seen that the purchase of fashion items online is mostly done by young shoppers, aged 15-34, due to the increasingly modern lifestyle of the people, the increasing needs and desires of the people; online store products that are a favorite in 2018 are fashion products.

\section{Literature Review}

\section{Marketing Strategy}

According to Tjiptono (1997) that marketing is a social and managerial process that makes individuals and groups get what they need and want through the creation and reciprocal exchange of products and values with other parties. The purpose of marketing is to influence the level, reach, time, composition of requests, thus helping the organization to achieve its goals. Marketing strategy is a fundamental tool planned to achieve company goals by developing a sustainable competitive advantage through the market entered and marketing programs used to serve the target market (Tjiptono, 1997).

Marketing strategies have an important role in a company. The marketing strategy serves to determine the economic value of the company, both the price of goods and services. There are three determinants of the price value of goods and services, namely: production, marketing and consumption. In this case, marketing is a part that connects between production and consumption activities.

104 | IQTISHODUNA Vol. 16 (2), 2020

http://ejournal.uin-malang.ac.id/index.php/ekonomi 


\section{Online Store}

According to Setiawati (2014) that an online store is a store that offers goods and services through the internet, where visitors can view items that are in the online store in the form of visual or audio visual. The meaning of an online business is often assumed by internet marketers. This means that all businesses carried out online using internet media as a marketing media for products and services include parts of the online business. The advantages of online stores compared to offline are: First, in addition to visitors who come who are really interested in it, manufacturers do not need to be bothered making pamphlets or making advertisements on offline media; Second, the online store does not have to be awaited, even the manufacturer just accepts orders if there are customers who are interested in the product. And third, the most effective means for promotion in the era of technological advancements. Because now the internet can be accessed anywhere. In short, the advantages of online business are not bound by time and place, wide market share, effective promotional media and capital and relatively small operational costs.

\section{Consumptive Behavior}

According to Mowen dan Minor (2002) that consumptive behavior is the tendency of a person to behave excessively in buying and using something irrationally and prioritizing desires rather than their needs. Consumptive behavior is a behavior of buying or using a product by not basing rational considerations and and having a tendency to consume something indefinitely where individuals prioritize desires rather than their needs, and are characterized by the existence of luxury or something that can provide satisfaction and comfort (Triyaningsih, 2010). To find out someone or consumer who has consumptive behavior can be seen from several indicators.

According to Sumartono (2002) in Astuti (2013) there are several indicators of consumptive behavior: First, Buy products because of the lure of prizes; second, buy products because of the attractive packaging; third, buy products to maintain their appearance and prestige; fourth, buy products based on price (not on the basis of benefits or uses); Buying products is just keeping a status symbol; fifth, use the product because of the element of conformity to the model that advertises; sixth, the emergence of an assessment that buying high-priced products will lead to high self-esteem; seventh, Try more than two similar products (different brands). 
Naning Fatmawatie

\section{Islamic Marketing}

According to Hasan (2009) that Islamic marketing or known as Sharia Marketing is the application of a strategic business discipline that is in accordance with Islamic values and principles. The point in sharia marketing is based on Islamic concepts taught by the Prophet Muhammad. This means that Islamic marketing covers the entire process, both the creation process, the bidding process, and the process of changing values, there must not be things that conflict with the contract and the legal principles of muamalah.

In the era of free trade, every company faces intense competition. Increasing competition intensity from competitors requires companies to always pay attention to the needs and desires of consumers and try to meet consumer expectations by providing more satisfying services than those carried out by competitors. Thus, only quality companies can compete and dominate the market. The strategy that can be used to improve and maintain customer loyalty is by applying Islamic marketing. Islamic learning is a form of marketing that is based on Islamic law, on Islamic regulations, and does not conflict with these regulations. The Islamic marketing characteristics are: first, Godliness (rabbaniyah), religious nature: The belief that the sharia laws are laws that are the most just and perfect law and the feeling that God always watches over them; second, Ethics (akhlaqiyyah), prioritizes moral problems (moral and ethics) in all aspects of its activities; third, Realistic (alwaqi'yyah), not an exclusive concept, fanatical, anti-modern, and rigid, but flexible in the corridor of sharia; and fourth, humanistic (insaniyyah), is universal humanistic.

\section{Islamic Consumption}

According to Zulfikar dan Mepi (2014) that consumer behavior will have an influence on their motives in carrying out consumption. In conventional consumption behavior will place personal interests and utilitarianism which aims to maximize satisfaction on the philosophical basis of "Rational Economic Man", "positivist", and "legal compliance". Whereas in consumption behavior in Islam, the motive is based on the principle of justice, the cleanliness, the simplicity, generosity, and morality. Because consumption is essentially issuing something in order to meet needs.

Consumption includes needs, fun and luxury. Islam has arranged all consumption activities of course according to what is contained in the Qur'an and al-Sunnah. Consumption behavior that is in accordance with the provisions of the Qur'an and al-Sunnah will bring the culprit to reach 
blessings and the welfare of his life. Islamic Shariah wants humans to achieve and maintain their welfare. The broader meaning is the achievement of maslahah. Maslahah is the nature or ability of goods and services that support the basic elements and objectives of human life on this earth.

\section{Research Methodology}

The research is descriptive with a qualitative approach. The information determination technique used is a purposive technique. In reviewing marketing strategies in online stores and their implications for consumptive behavior on IAIN Kediri student fashion products using the perspective of Islamic marketing and Islamic consumption. Data collection used observation, interviews and documentation. While analysis techniques used data reduction, data presentation, and conclusion.

\section{Research Result And Discussion}

\section{Application of Marketing Strategies at Online Stores in Indonesia}

Table 1. Data on students of IAIN Kediri who shop at online stores

\begin{tabular}{lc}
\hline Name of online shop & Number of students \\
\hline Shopee & 95 \\
Lazada & 135 \\
Tokopedia & 75 \\
Bukalapak & 45 \\
Bli-bi & 30 \\
Zilingo & 15 \\
Other online shop & 5 \\
\hline Amount of & $\mathbf{4 0 0}$ \\
\hline
\end{tabular}

Based on the above data it can be seen that information from 400 students who are representatives of 3 Faculties of IAIN Kediri namely, Sharia, Tarbiyah and Ushuludin who shop at online stores can be seen that the most popular online store is Lazada. Lazada is an online store that has the most visitors in the first quarter of 2018 in Indonesia with 117.6 million visitors. Lazada even occupied the first position followed by Tokopedia, Bukalapak, Bli-bli and Shopee with the number of visitors in a row as many as 117.3 million, 93.6 million, 45.9 million and 34.5 million visitors (Lazada, 2019). In addition, from Bisnis.com Jakarta-Platform, Lazada buying and selling, closes 
the Lazada 12.12 Grand Year End Sale program by setting the highest transaction record in the National Shopping Day 2018 with an increase in the number of orders 18 times the usual day. In Lazada 12.12 Grand Sale Year in 2018, the categories of fashion, beauty, mother and child and electronics are the favorites of consumers.

To reach the position of dominating the trade market in Indonesia, the marketing strategy implemented by online stores: conducting marketplaces, offering low prices, free shipping services and giving bonuses.

\section{Consumptive Behavior in IAIN Kediri Student Fashion Products}

Table 2. Data on product types purchased by IAIN Kediri students

\begin{tabular}{lc}
\hline Type of Product & Number of students \\
\hline $\begin{array}{l}\text { Fashion (male and female fashion, watches, } \\
\text { accessories and cosmetics / beauty) }\end{array}$ & 355 \\
$\begin{array}{l}\text { Electronics (equipment, accessories, TV and } \\
\text { home electronics and digital products) }\end{array}$ & 45 \\
$\begin{array}{l}\text { Household needs } \\
\text { Outomotive }\end{array}$ & - \\
$\begin{array}{l}\text { Home needs and lifestyle } \\
\text { Sports }\end{array}$ & - \\
\hline Amount of & $\mathbf{4 0 0}$ \\
\hline
\end{tabular}

Based on the above data it can be seen that, the majority of students of IAIN Kediri purchase at the online shop for fashion products. Fashion products include: men's and women's fashion, watches, accessories and cosmetics or beauty.

Table 3. Data on the frequency of product shopping fashion

\begin{tabular}{lc}
\hline Shopping frequency & Number of students \\
\hline 1 time a month & 175 \\
$>1$ time in 1 month & 150 \\
$<1$ time in 1 month & 75 \\
\hline Amount of & $\mathbf{4 0 0}$ \\
\hline
\end{tabular}


Based on the Table 3, it can be seen that, students do shopping more than once a month and spend 1 time in a month 325. This shows that students are very consumptive once making purchases at online stores.

Based on the Table 4, it is known that the dominant factor of the IAIN student Kediri in fashion product consumptive behavior in online stores is lifestyle, attitude and belief factors.

Table 4. Data on the factors that influence consumptive behavior of fashion products

\begin{tabular}{lc}
\hline $\begin{array}{l}\text { Factors that influence Consumptive behavior } \\
\text { of fashion products in online } \begin{array}{c}\text { Nores } \\
\text { students }\end{array}\end{array}$ & \\
\hline Culture & \\
Subculture & 30 \\
Social Class & \\
Rerefence group & \\
Family & \\
Role and Status & \\
Age and life cycle stage & \\
Work & 240 \\
Economic conditions & \\
Life style & \\
Personality and self-concept & 30 \\
Motivation & \\
Perception & 100 \\
Learning & $\mathbf{4 0 0}$ \\
Attitude and Confidence & \\
\hline Amount of & \\
\hline
\end{tabular}

\section{Implementation of Marketing Strategies at Stores in Indonesia in Terms of Islamic Marketing}

Marketing strategies that are applied online stores include: doing marketplace, offering low prices, free shipping service and giving bonuses. Marketplace strategy is a place that brings together sellers and buyers online. The advantage of the marketplace is that sellers may not have to have their own online store site to sell the products they have. Whereas from the buyer side, it might be easier to find various types of items they need. This means that there is no need to pay for buying or selling goods. In the end, for the

IQTISHODUNA Vol. 16 (2), 2020 |109

http://ejournal.uin-malang.ac.id/index.php/ekonomi 
seller he can offer a cheaper price to the buyer because efficiency has occurred. According to Kertajaya dan Syakir (2006) that Islamic marketing that marketplace strategies can be done because of the benefit between sellers and buyers. The origin of this strategy is done by directing the process of creating, offering and changing values from one party to stakeholders. Of course the whole process must be in accordance with the contract and principles of muamalah in business in accordance with Islamic principles. In the marketplace, because there is a meeting between the seller and the buyer online, it still must lead to Islamic marketing principles, namely humanistis (insaniyyah), namely the existence of universal humanistic, namely that sharia is created for humans so that their degrees are elevated, their human nature is maintained and maintained, and their animal characteristics can be restricted by sharia guidelines. Islamic sharia was created for humans according to their capacity regardless of race, color, nationality and status.

The free shipping service strategy is carried out because sometimes in certain cases shipping costs can be more expensive than the price purchased, so that by free shipping costs, buyers only need to pay the price of the goods they buy. But if the delivery fee exemption is only for promotions to increase sales and charge shipping costs with the price of goods offered, of course this is not justified. According to Islamic marketing, the free shipping service strategy can be carried out with integrity, honesty and transparency, so as to foster consumer trust. This strategy is based on Islamic marketing principles, namely Realistic (al-waqiyyah). Although transactions are carried out online, but as professional marketers, they must adapt religious values, piety, moral aspects and honesty in all marketing activities.

The strategy of giving bonuses is given so that buyers buy within the specified time period. This certainly encourages buyers to buy emotionally and not rationally. For a moment the seller's goal is reached, but if the product sold is not accompanied by good quality, it will certainly make consumers disappointed. According to Islamic marketing that the whole process, both the process of creation, the bidding process, and the process of changing values, there must not be things that are contrary to the contract and Islamic principles of muamalah. As long as this can be guaranteed, and the deviation of Islamic muamalah principles not occurring in any transaction in marketing can be allowed. In implementing a strategy of giving bonuses, marketers must hold the Islamic marketing principle of Ethics (akhlaqiyyah) prioritizing moral (ethical) problems in all aspects of their activities, because moral and ethical values are universal values.

110 | IQTISHODUNA Vol. 16 (2), 2020

http://ejournal.uin-malang.ac.id/index.php/ekonomi 


\section{Consumptive Behavior in Fashion Products of IAIN Kediri Students is Viewed from Islamic Consumption}

Based on Tabel 1, it can be seen that the majority of IAIN Kediri students shop at Lazada's online store. This is in accordance with the data shown from Bisnis.com Jakarta-Platform, Lazada buying and selling, closing the Lazada 12.12 Grand Year End Sale program by setting the highest transaction record in the 2018 National Shopping Day. In table 2, it can be seen that favorite products purchased from online shop of IAIN Kediri students is fashion. This is in accordance with the data contained in Lazada 12.12 Grand Sale Year in 2018, the electronic fashion category that is a favorite of consumers. Based on table 3, it can be seen that the frequency of purchasing fashion products in the online shop of IAIN Kediri students is 1 times in one month and more than once in a month. In table 4, it can be seen that the factors that the student has the majority consumptive behavior due to lifestyle, then followed by attitudes and self-confidence. The above conditions when associated with Islamic consumption that the phenomenon of the many online stores with its precise marketing strategy has made students forget their basic needs as students. He prefers his satisfaction by consuming fashion for the sake of pleasure and luxury. Especially with excessive spending that exceeds the limits needed by the body, in its position as a student.

This is not in accordance with consumption in Islamic teachings. According to Fauzia (2013) that consumption behavior in Islam must be based on the principle of justice, the principle of cleanliness, the principle of simplicity, generosity, and morality. Consumption is not just to meet the needs of individuals, as consumers in order to fulfill the command of Allah SWT, but further implicates the awareness regarding the individual needs of others. For this reason, in the context of the ability to consume sustenance from Allah SWT, at the same time there is a responsibility to pay attention to the needs of the lives of people who do not have, both those who do not ask (al-Qani') or those who ask (al-Mu'tar), for people who are miserable and needy. Even consumption for a Muslim is only an intermediary to increase the power of obeying Allah, which has a positive indication in his life. Indeed a Muslim will not harm himself in the world and in the hereafter, because it gives him the opportunity to be able to fulfill his consumption at a level beyond the limit, making him busy pursuing and enjoying world pleasures so that he neglects his main task in this life. 


\section{Conclusion}

Online store marketing strategy in Indonesia applies marketplace, low prices, free shipping and bonus services; IAIN Kediri students spend more through Lazada's online store, with favorite fashion products. The frequency of shopping for fashion products at online stores is at most once a month and more than 1 month. Factors that encourage them to behave consumptively are dominant because of lifestyle factors and attitudes and self-confidence.

The implementation of marketing strategies to online stores must be based on the theistic principles (rabbaniyyah), ethical (akhlaqiyyah), realistic (al-waqiyyah) and humanistic (insaniyyah); The behavior of fashion product consumers at the online shop of IAIN Kediri students is not in accordance with Islamic consumption, because their consumption behavior is not based on the principle of justice, the principle of cleanliness, the principle of simplicity, generosity, and morality. Consumption is not just to meet individual needs, as consumers in order to fulfill the commands of Allah SWT.

\section{Reference}

Abdel, B., Hasouneh, A., Marzouq, A. (2010). Measuring The Effectivenessof E-mail Direct Marketing in Building Customer Relationship. International Journal of Marketing Studies.

Adelaar, T. (2000). Electronic Commerce and Implifications for market Structure: The Example of the Art and Antiques Trade. Journal of Computer-Mediated Communication , 5 (3).

Alsubagh, Helal. (2015) The Impact Of Social Networks On Consumers Behaviours. International Journal of Business and Social Science, 6(1), 209-216.

APJII. 2017. Penetrasi dan Perilaku Pengguna Internet Indonesia: Survey (Diakses pada tanggal 4 Juni 2018)

Astuti, E. D. (2013). Perilaku Konsumtif Dalam Membeli Barang Pada Ibu Rumah Tangga di Kota Semarang. E-Journal Psikologi Fisip Unmul, 1(2), 148-156.

Fauzia, I. Y. (2013). Etika Bisnis Dalam Islam. Jakarta: Kencana Prenada Media Group.

Hasan, A. (2009). Manajemen Bisnis Syariah. Yogyakarta: Pustaka Pelajar. 
Iblasi, W. (2016). The Impact of Social Media as a Marketing Tool on Purchasing Decisions (Case Study On Samsung for Electrical Home Appliances). International Journal of Managerial Studies and Research, 4(1), 14-28.

Kartajaya, H. dan Syakir, S. M. (2006). Syariah Marketing. Bandung: Mizan.

Khairunissa. (2014). Dampak Aplikasi Istagram Terhadap Perilaku Konsumtif Remaja Dalam Berbelanja Online Dikalangan Siswa Siswi SMA SMA Negeri 2 Tenggarong. E-Journal Ilmu Komunikasi, 2(4): 220-230.

Kotler dan Armstrong. (2009). Prinsip-prinsip Pemasaran, Erlangga: Jakarta.

Lazada e-Commerce paling banyak pengunjung TW 1 2018. Databoks on line, http://www, data.boks.katadata.co.id, 18 April 2018, diakses tanggal 26 Februari 2019.

Mowen, J.C., dan M. Minor. (2002). Perilaku Konsumen, Penerjemah: Lina Salim. Jakarta: Erlangga.

Nurdin, N. (2017). To Research Online Or Not to Research Online: Using Internet Based Research In Islamic Studies Context. Indonesian Journal of Islam And Muslim Societis, 7(1), 31-54.

Pasha, R. M. Kemudahan yang didapat dari belanja online, (Diakses pada tanggal 21 Mei 2017)

Rahman, M. A. (2016). Pengaruh Penggunaan Media Sosial Terhadap Keputusan Pembelian Lewat Internet di Kalangan Mahasiswa . In Assets, 6(1), 103-115.

Setiawati, I. (2014). Pengaruh E-Marketing Pada Bisnis Online Menggunakan Media Sosial (Stusi Deskriptif Kualitatif), Seminar dan Call For Paper, FEB, Universitas Stikubank, Semarang.

Tjiptono, F. (1997). Strategi Pemasaran, Yogyakarta: ANDI OFFSET.

Triyaningsih. (2010). Dampak Online Marketing Melalui FaceBook Terhadap Perilaku Konsumtif Masyarakat. E-Journal Ekonomi dan Kewirausahaan, 11(2), 172-177.

Omar, Maktoba, Bathgate, Ian. (2011). Internet Marketing and Customer Satisfaction in Emerging Market : the Case of Chinese Online Shoppers. Competitiveness Review An International Business Journal incorporating Journal of Global Competitiveness, 21(2), 224-237. DOI: 10.1108/10595421111117489. 
Naning Fatmawatie

Zulfikar dan Meri. (2014). Implementasi Pemahaman Konsumsi Islam Pada Perilaku Konsumen Muslim. Jurnal JESTT, 1(10), 736-754.

Kompas.com, 2018

Onlineterpercaya.com, 2017

Data APJII, 2018 